\title{
Global imbalances, monetary disorder, and shrinking policy space: Keynes's legacy for our troubled world
}

\author{
Anna M. Carabelli* and Mario A. Cedrini*
}

\begin{abstract}
The paper aims at showing that revisiting Keynes's early writings on international economic relations and some less well-known episodes of his economic diplomacy, with special attention being paid to the methodological issues involved, may disclose useful insights in understanding the features of his desired new global order. We contrast the three main pillars of Keynes's vision as detected in this revisitation (coordinated multilateral responses to global imbalances, a rational international monetary regime, and enhanced policy space) with the major shortcomings of the current non-system, and show the continuing relevance not only of Keynes's specific proposals for global reform, but also, and most importantly, the legacy of his way of reasoning about international economic relations.
\end{abstract}

JEL classifications: B3I, Fo2, B4I

Keywords: John Maynard Keynes, international economic order, Bretton Woods II

* Università del Piemonte Orientale, Italy.

Correspondence Address:

Mario A. Cedrini, Università del Piemonte Orientale »Amedeo Avogadro«-Alessandria, Novara, Vercelli, Department of Economics and Quantitative Methods (SEMeQ), Via Perrone I8, 28Ioo Novara, Italy, e-mail: mario.cedrini@eco.unipmn.it.

Received I6 January 20I0, accepted o6 May 2010

C INTERVENTION 7 (2), 20IO, 303-323 


\section{Introduction}

Keynes is back. The financial crisis has succeeded in promoting both a return to Keynesian national policies and, even more interestingly, a rediscovery of Keynes's international economics. It is not difficult to detect evidence of the continued relevance of his reform plans for Bretton Woods in the bulk of proposals for international monetary reform that have been recently suggested as a way out of the crisis. Expert committees of international institutions are debating with unusual passion on the two main pillars of Keynes's project for an International Clearing Union (ICU), i.e. the need of shifting part of the responsibility for international imbalances to creditor countries, and the establishment of a true supranational currency (see UNPGA 2009 and the surprising emphasis put by Zhou Xiaochuan (2009: 2), the Governor of the People's Bank of China, on the desirability of a new »international currency unit, based on the Keynesian proposal«).

However, Keynes's legacy for our world is not limited to a series of specific recommendations on how to reform the international architecture. Among the themes to be rediscovered in Keynes's work, Kirshner (2009: 527) correctly places »the potentially fragile underpinnings of international economic order " and the "inherent dysfunctions of the international monetary economy «, and insists on the relevance of "Keynes's philosophy and its relationship to economic inquiry«. Likewise, Vines (2003:358) argues that the rediscovery of Keynes should be accompanied by a revisitation of the "focus and method « of his work, which shows his "extraordinarily clear understanding of how pieces of the global economy interact, driven by the policies of autonomous nations, in an only partly coherent manner" (339). In line with these suggestions, this paper aims at showing that revisiting Keynes's early writings on international economic relations (The Economic Consequences of the Peace, Indian Currency and Finance) and some less well-known episodes of his economic diplomacy (his proposal of an American gift to Britain at the end of World War II), with special attention being paid to the methodological issues involved, may disclose useful insights in understanding the wisdom of Keynes's Bretton Woods plans for international reform. In so doing, we contrast the three main pillars of Keynes's vision of international economic relations as detected in this revisitation, namely, coordinated multilateral responses to global imbalances, a rational international monetary regime, and enhanced policy space, with the major shortcomings of the current non-system, and show not only the continuing relevance of Keynes's specific proposals for global reform, but also, and foremost, the legacy of his general vision and way of reasoning about international economic relations for our troubled world.

\section{Keynes and the complexity of international economic relations: The Economic Consequences of the Peace}

Keynes considered economics to be "a branch of logic, a way of thinking [...] in terms of models joined to the art of choosing models which are relevant to the contemporary world" (The Collected Writings of John Maynard Keynes - hereafter: CW I4: 296 - 97). Remarkably, 
he believed it to be in the "nature of economic thinking « to cope with the complexity of the economy without abstracting from variability, as he wrote in the General Theory,

"after we have reached a provisional conclusion by isolating the complicating factors one by one, we then have to go back on ourselves and allow, as well as we can, for the probable interactions of the factors among themselves« $\left(C W_{7}: 297\right)$.

The notion of "complexity and interdependence«, which characterizes his methodological approach to probability (see Carabelli 1988), recurs frequently in Keynes's mature economic writings (e.g. $C W$ I: I82; $C W 8: 298$ ). For Keynes, the need to work with complex magnitudes - such as purchasing power, real income, and the general price level, that are "capable of variations of degree in more than one mutually incommensurable direction at the same time« ( $C W_{5}$ : 88) and, due to their heterogeneity, raise problems of measurement and comparison - combines with the organic interdependence that binds them one to another, so that

"the atomic hypothesis which had worked so splendidly in physics breaks down in psychics. We are faced at every turn with the problem of organic unity, of discreteness, of discontinuity - the whole is not equal to the sum of the parts, comparison of quantity fails us, small changes produce large effects, the assumptions of a uniform and homogeneous continuum are not satisfied « ( $C W$ IO: 262).

The atomic hypothesis breaks down also at the social level: complexity and interdependence lie at the basis of the dilemmas, paradoxes, and conflicts between individual and social interests that Keynes's macroeconomics is intended to counteract (Carabelli/De Vecchi 200I). Likewise, a distinctive trait of Keynes's vision of international economic relations as a complex object is the use of a peculiar method of investigation that enables him to tackle organic interdependence among the variables of a system characterized by openness, incompleteness, indivisibility, contingency and chance.

The most vivid illustration of Keynes's refusal to apply the »atomic hypothesis « in international economics is offered by The Economic Consequences of the Peace (ECP; see Carabelli/Cedrini forthcoming). Keynes was persuaded that the Treaty of Versailles »ignores the economic solidarity of Europe, and by aiming at the distruction of the economic life of Germany it threatens the health and prosperity of the Allies themselves" ( $C W_{\text {I7 }}$ : 58). The "economic unity of Europe« rested in fact, he wrote, on the economic and territorial integrity of Germany, the heart of the European »body« $\left(C W_{2}: 2\right)$, and »on the prosperity and enterprise of Germany the prosperity of the rest of the Continent mainly depended « (9). In his vision, the highly punitive dispositions of the Treaty on German coal and iron were leading European policymakers into a »real dilemma" (58). France and Italy's attempt to save their industry by securing reparations in kind from Germany possessed "unanswerable force from a certain point of view« (ib.); yet, in case of surrender of German coal, Northern Europe and Austria-Hungary would have been compelled to recur to »international barter« (59) with Germany, which France and Italy could not tolerate unless the treaty's obligations were met first: 
"In this there will be a great show of justice, and it will be difficult to weigh against such claims the possible facts that, while German miners will work for butter, there is no available means of compelling them to get coal, the sale of which will bring in nothing, and that if Germany has no coal to send to her neighbours she may fail to secure imports essential to her economic existence« (6o).

Keynes described the European situation as an "impending catastrophe« with "all the elements of ancient tragedy " (3). A moral conflict for the European body charged with the settlement of the continent, the coal settlement assumed the forms of a rational dilemma for France and Italy:

»If the European Civil War is to end with France and Italy abusing their momentary victorious power to destroy Germany and Austria-Hungary now prostrate, they invite their own destruction also, being so deeply and inextricably intertwined with their victims by hidden psychic and economic bonds« (2).

"Men have devised ways to impoverish themselves and one another and prefer collective animosities to individual happiness « (62), Keynes observed on discussing the struggle between, on the one side, nationalism and "private interest « and, on the other, "sentiment and historic justice $(60)$ and the future prosperity of the continent. In »so complex a phenomenon" (I60), the only way out of the impasse ("a case where particular interests and particular claims, however well founded in sentiment or in justice, must yield to sovereign expediency«, ib.) lay in the cancellation of inter-allied debts, allowing the European claimants to recede from asking impossible reparations of Germany. As Keynes was to explain in The End of Laissez-faire, the cure for the fallacy of composition between particular and general interests, which is typical of worlds characterized by complexity and interdependence, lies "outside the operations of individuals" ( $C W_{9}$ : 29I); it has a social character and is provided by public institutions able to "exercise public action grounded upon deliberate and reasonable [...] judgement« (Carabelli/De Vecchi 200I: 234).

Being aware that, since "interdependence required management «, "a ^leader» was a great asset (if not an essential one) in doing this" (Markwell I995: 209), Keynes was to express his hopes for a renewed leadership of Britain, possessing the "experience or the public spirit " $\left(C W_{9}: 236\right)$ to counteract the "competitive struggle for liquidity « $(C W 2 \mathrm{I}: 42)$ - an "extreme example of the disharmony of general and particular interests" (52) - nurturing the world slump of 1931. Likewise, in I919, the "appeal to the generosity of the United States" ( $C W 2$ : 93) and Britain, which should provide the European creditors with an "alternative mode of escape from their troubles« (94), was an "absolutely essential« (I7I) precondition to face the reparations problem. As an "act of farseeing statesmanship « (93) on the part of the two powers, combining "expediency and generosity (I79), debt forgiveness should have promoted, but at the same time required as its precondition, an "honorable attempt « on the part of the European countries "not to continue war, economic or otherwise, but to achieve the economic reconstitution of the whole Continent" (I73). As Keynes pointed out, 
"the financial problems which were about to exercise Europe could not be solved by greed. The possibility of their cure lay in magnanimity. Europe, if she is to survive her troubles, will need so much magnanimity from America, that she must herself practice it $"$. (92)

After the United States's refusal to renounce its share of inter-allied debts, Keynes presented the proposal of an international loan asking winners, losers and even neutral countries to take part in the "grand scheme for the rehabilitation of Europe" (CW I6: 428). Yet, in the ECP, the proposal lies in continuity with, and logically follows, the plan to eliminate Inter-Allied indebtedness. The European conflict could not be settled unless the ignition key provided by the American assistance to the continent - a gift element acting as a strange attractor (Godbout 1998) - allowed a spiral movement of "magnanimity« to spread along, and progressively expand, the chain of countries disposed to take part in Keynes's sharedresponsibilities scheme.

\section{Keynes's desired new order and the proposal of an American gift}

The main aim of Keynes's work as an international economist and negotiator was to revamp the "lost paradise" (Dimand 2006: I75) of the pre-I9I4 internationalization he had described in the opening pages of the ECP, a task made difficult by what he came to define, in the Treatise on Money, as the "dilemma of the international system", that is the double need - already dealt with in A Tract on Monetary Reform -

"to preserve the advantages of the stability of the local currencies of the various members of the system in terms of the international standard, and to preserve at the same time an adequate local autonomy for each member over its domestic rate of interest and its volume of foreign lending ( $C W 6: 272)$.

For the first time in recent history, Keynes noted, Britain was not able to influence world credit conditions any longer, and found herself exposed to the constraints of the dilemma. Keynes's proposal for a new international leadership of Britain in I93I was a direct attack on the "anti-social « (CW 2I: 53) behaviour of America and France, who "have not lent their surplus balance on international account as Great Britain used to do in the past " $\left(C W_{2}\right.$ : 6oo). On proposing the plan for an International Clearing Union (ICU) in the Forties, he was to recall that Britain had provided the pre-war international system with a leadership able and willing to limit the strict discipline of the classical mechanism, by sharing the adjustment burden with debtor nations. By investing long term in the new countries - the process, Keynes argued in his 1929 lectures, »by which rich countries spread the proceeds of their wealth over the world « (Fleming, 2000: I42) -, Britain had granted them the possibility to live and develop in a multilateral system. While progressively elaborating a view of economic history as a permanent conflict between creditors and debtors (De Cecco 200I), Keynes came to assign himself the task of sketching a model of national behaviour consist- 
ent with the general interests of the system (Moggridge 1986), and found it in the "twice blessed « $\left(C W_{7}\right.$ : 349) policies of regaining control over the interest rate, whereby countries could reach and maintain full employment and help their neighbours, at the same time, to achieve this same result.

Keynes's projects for global cooperation in the Forties reflected his desire "to achieve by multilateral cooperation what British leadership of the international economy had once done" (Markwell 2006: 26I). The interwar period had instructed him about the risks a system has to tolerate when it depends so critically on the willingness of its most powerful members to respect the rules of the game. The ICU plan was more than a contingent solution to "the outstanding economic problem of the post-war world [...] [i.e.] how the U.S.A. is to redress her unbalanced creditor position« ( $C W_{27}$ : I9); more ambitiously, it should have laid the foundations of "a sounder political economy between all nations ( $C W_{25}$ : 43), by establishing "a system of general and collective responsibility, applying to all countries alike, that a country finding itself in a creditor position against the rest of the world as a whole should enter into an obligation to dispose of this credit balance and not to allow it meanwhile to exercise a contractionist pressure against the world economy and, by repercussion, against the economy of the creditor country itself « (47). The plan directly asked creditor countries to make available the resources they chose to leave idle or accumulated due to a lack of investment opportunities at home. But it was not its intention to favour an "automatic surrender of surpluses " (in Skidelsky 2000: 213); rather, Keynes's scheme aimed at building a postwar system "where bilateralism would be unnecessary and multilateralism would again be practicable« (Williamson I98I: 542). In this sense, as Moggridge (I992) notes, Keynes was truly making a case for the disarmament in international economic relations.

This helps explain how the ICU, a »refinement and improvement of the Schachtian device« ( $C W$ 25: 24) - the system of bilateral clearing agreements established by Germany in wartime with European and Latin American countries to conduct trade as an international barter centered on Berlin - came to represent the ideal alternative to Schachtianism itself. Unlike laissez-faire and not dissimilarly from Schachtianism, the »banking principle» (277) of the ICU would have reduced, the economic problem of international adjustment. Yet, by placing emphasis on the virtues of economic interdependence, its "system of general and collective responsibility« could afford the task without locking each country in "a position of particular obligation towards others" (46). »Everything else in the plan«, wrote Keynes, »is ancillary« to multilateralism (270). Though starting from a national perspective (Newton 2000), thereafter, Keynes came to develop "a theory of how the system as a whole would behave« (Vines 2003: 349). Fear either of a global restraint after the war, or lest the United States could make use of means other than increased domestic demand to sustain full employment, led Keynes to grant the ICU the possibility to create reserves as required by the needs of international trade (Turnell 2002) in a context of fixed but adjustable exchanges and capital controls, with national monetary policies to aim at internal equilibrium (see Vines 2003). Once reconsidered to the light of the dilemmas of the international system Keynes had exposed in the Treatise, the ICU plan appears as a device to transform international discipline into the choice of freedom of the General Theory. 
Keynes's plans were finally rejected at Bretton Woods by the United States, who strongly limited the resources available to the newborn international institutions to cope with the transition to the new order. A financially exhausted Britain had held the European fort alone during the first years of the war and incurred enormous debts with the sterling area countries to finance the common effort. Scarcity of reserves and expected peacetime difficulties in exporting goods and services were serious threats to the chances of balancing Britain's external account in the transition period while returning to sterling convertibility. The prospected expiration of the Lend Lease Agreement with the United States led Keynes to design, in his memorandum "Overseas Financial Policy in Stage III « of March 1945, a »bold scheme for an international policy of multilateralism in trade and payments that would simultaneously make sterling's problems more manageable and justify Britain in seeking and America in giving financial assistance " (Pressnell 1986: 237). Keynes explained the rationale of the plan in the press conference at the beginning of the Washington negotiations. Global interdependence (»the financial and commercial arrangements of a considerable section of the world have become almost inextricably intertwined with our own financial and economic affairs in London «) was the key to understand why a resolution of Britain's imbalances could serve the cause of the newborn multilateralism:

"We have to look at the financial and commercial problem of the world as a whole; and, moreover, build up a currency and commercial structure which is in the best interest not only of world prosperity [...] but of peace and goodwill amongst men [...] so as to avoid the violent disturbance of international commerce which are the road to discontents which can shake the social order and to maintain full employment and good wages everywhere by means that do not beggar but, on the contrary, enrich our neighbours« $(C W 24: 465)$.

In the memorandum, Keynes pictured three different scenarios for Britain. A lack of American assistance would have compelled her to a "Starvation Corner" unilateral policy of austerity and isolationism at a moment when, due to the overall deficit of the sterling area, London had inevitably to resort to foreign borrowing to finance her debts. What is more, the Starvation Corner and its Schachtian consequences would have favored

"not merely the acceptance but the advocacy [...] of a system of international economy after the war of a kind to which all sections of opinion, not only in the United States but also in Canada, are bitterly opposed« $(27 \mathrm{I}-72)$.

As an alternative to isolationism, Keynes first envisaged American financial assistance in the form of a loan ( $\$ 5-8$ billion) on easy terms - Temptation" - , allowing Britain the breathing space to face the transition to the new order and to approach its debt problems with the sterling area. In exchange for the loan, causing »the sweet breath of Justice between partners" in the war to be "sacrificed to some false analogy of `business« (279), London would have guaranteed free multilateral clearing within the area from the outset and the dismantlement of the empire; in short, the acceptance of the "American conception of the international 
economic system «, which Roosevelt had already established as the price of the Lend-Lease agreement. Keynes's own favorite option, "Justice«, required "a general re-consideration of the proper burden of the costs of the war « to allow Britain to be the Americans' partner »in setting up a post-war international economy of the character on which they have set their hearts « (280). The United States should have granted Britain $\$ 3$ billion as a sort of retrospective Lend-Lease agreement and a $\$ 5$ billion credit line at easy conditions. In exchange, London would have ensured the de facto convertibility of sterling, after approaching her sterling area creditors with a tripartite program of eliminating ( $£ 880$ million), funding ( $£$ I. 5 billion), and freeing ( $£ 750$ million) the $£ 3$ billion balances.

Here lies, according to Skidelsky, the main mistake made by Keynes in "fighting for Britain «: he wrongly "persuaded himself, against all the evidence, that he could obtain a large gift from the United States to cover Britain's temporary post-war balance of payments deficit, without any unacceptable strings (Skidelsky 2000: xvi). That Keynes's proposal for the "American gift « has gained little attention by the economic literature is scarcely surprising: the final agreement with the Americans was on a $\$ 3.75$ billion loan on easy terms. Historians tend however to argue that Keynes's proposal was but a strategic camouflage of the expected loan, or "an attractive marker, to compare the most favourable possible outcome with the least favourable« (Pressnell 1986: 265). To throw light on Keynes's proposal as distinct from what has been finally agreed on by the British negotiation team, one has to go back the correspondence, in Spring 1945, between Keynes and the treasury representative in Washington, Robert H. Brand (see Cedrini 20Io).

Commenting on Keynes's memorandum, Brand wrote that Britain should refrain from claiming, on the basis of American late entry into the war, that "what we propose is not only Justice to us, but also Justice for them « $\left(C W_{24}\right.$ : 307): better, then, to ask for »something that looked a little less like a free gift« (308). Keynes replied by observing that since " $\mathrm{t}]$ he various elements in the policy of trying to march with the US in the post-war economic set-up all hang together«, only a gift, and certainly not the »distasteful« second-best policies imposed by the Temptation option, "would enable us to march with them side by side» (316) towards a new world. He was firm on the need to reject "anything in the nature of a specific bargain « (324): justice and generosity could agree together, whereas »too exclusive an appeal to American self-interest will be misjudged « (360). True, since the United States was a "business country", as he later wrote in a memorandum to Hugh Dalton, "some imitation of a normal banking transaction" was necessary (548): yet Keynes only specified that in exchange for the gift, Britain should be ready to accept »the kind of post-war world « wanted by the Americans, a multilateral world of free trade that, in the absence of a gift, "they would fail to get, here and now « (328). To reassure the United States about the participation of the Sterling Area countries to the reconstruction of Britain, Keynes proposed that "the $\$ 3$ billion from the US should be matched by cancellations by the sterling creditors of an at least equal amount « (324). Brand was right to observe that the free gift required "an atmosphere totally different from anything like the present one« (332). Still, Keynes explained that the gift would have facilitated the task of prompting the sterling area countries to fall in with the proposal: "If America insists on remaining on a strictly economic basis, that makes it 
harder for the others to depart from it. I attach predominant importance to this psychological atmosphere of the free gift« (340).

The continuity between, on one side, Justice as a model of international adjustment that uses a "gift dynamics" to promote a multilateral resolution of the imbalances, and Keynes's attempt, in 1919, to provide Europe with a means of escaping from the irreducible dilemmas of reparations and inter-allied debts, can scarcely be undervalued. The involvement of a third actor - European creditors at the end of the First World War and the sterling area in 1945 - in a process which looks like a bilateral relationship, is typical of gift-giving situations: it throws light on the systemic character of gifts, which link together "many partners in a chain, creating a complex path (Godbout 2000: 130). The spyral dynamics of the gift assigns a prominent role to giving as the starting mechanism of a "strange law of alternation « (134), which requires the receiver not so much to reciprocate, but to offer himself. The moving from the Starvation Corner toward Justice, passing through Temptation, is thus to be symbolically seen as the progressive enlargement of the spectrum of countries taking part in the adjustment to a more equilibrated world, with the American gift as the starting mechanism of this chain of generosity. In effect, Justice was the sole possibility for the sterling countries - in a world primarily depending on American home trade, they were the only nations, together with Latin America, that could act as stimulators for American exports (De Cecco 1979) - to revitalize their exchanges with America without repudiating the agreements with Britain. It was an imaginative solution to let the main trade partners of a highly imbalanced world regain confidence to take part in global multilateralism, via the defence of Britain's economic destiny, as sadly confirmed by the transformation of the American Loan into a non-British demand for American goods and the subsequent 1947 sterling convertibility crisis.

\section{Current global imbalances through the eyes of Keynes}

„Overseas Financial Policy in Stage III" reflected Keynes's vision of the international order as a complex structure, characterized by organic interdependence among its variables, and fallacies of composition that require "public-spirited " interventions by countries only indirectly involved in such conflicts in order to promote "shared responsibilities" approaches to the management of international imbalances. As noted by Vines (2003), the "threefold dramatization of choice" (Pressnell I986: 246) for Britain's (and the world's) economic future possesses a paradigmatic character, which makes the model of international adjustment Keynes exposed in the memorandum a preliminary guide to reassessing the nature of the problem of current global imbalances (see Carabelli/Cedrini 20IO). In effect, striking similarities appear between the current international situation and that of the immediate postwar age. In the memorandum, a former superpower is confronted with the depletion of its resources and an unsustainable external debt, due also to the country's century-long decline as an exporter. By far the only creditor country in 1945, America is today the system's deficit of last resort, whereas the rest of the world (ROW) registers a surplus. Not too 
differently from the sterling area countries after the Second World War, emerging Asian countries play a key role in the current world economy. Their "undervaluation-cum-intervention" strategies (UNCTAD 2006) have produced »the largest /foreign aid programme in world history « (Wolf 2005: 25) and, together with increased surpluses in Europe, Japan, oil producers, and other developing countries, allowed the world locomotive to systematically live above its means. Yet the current crisis compels the United States to a severe readjustment, with extremely painful repercussions for both the American economy and global multilateralism. Due to the use of different analytical strands to interpret the dynamics of global imbalances and to the endogenous character of America's current account balance (Truman 2005), an extremely high number of possible future scenarios have been offered to explain what appears, even in the times of the crisis, as a surprisingly persistent pattern of international economic relations. Still, the literature has so far paid little attention to the type of adjustment - unilateral, bilateral, or multilateral - each suggested scenario is tied to.

Some of the most assertive views center on one or the other of the two main players to enforce adjustments of a wholly, or mainly, unilateral character. Chinn's (2005) »twin deficits" theory finds US tax cuts and large government expenditure responsible for increases in the current account deficit, and calls for a reduction in the budget deficit and foreign oil imports. Yet, there seems to exist no evidence for a true correlation between government deficits and current account deficits, nor can specific trade-related factors be said to explain adequately the latter. A mirror image of the "twin deficits" theory is provided by Bernanke's (2005) "global savings glut" hypothesis, which suggests that high rates of saving and depressed levels of capital investment in Asia are crowding in the United States' deficits. Bernanke argues - but Chinn's view leads to the same conclusion - that dynamic emerging countries should be helped to reassume their "more natural (2005: IO) role as international borrowers through structural and financial reforms of the kind of those promoted, with outstanding failures, in the years of the Washington Consensus. As known, this sexit strategy is ruled out by the practical impossibility, for Asian countries, of moving toward a floating exchange rate without risks of overheating and speculation. Moreover, the view underestimates the fact that »if the surplus regions were to reduce their financing to the United States, they would not be re-allocating their ssavingsı elsewhere, but the process of generating these savings would itself be at stake" (UNCTAD 2005: I8). In the literature, such `made in v views of current imbalances easily transformed into Starvation Corner scenarios like that described by Keynes. The standard analysis based on capitalizing the US debt flows had induced various academics to foreshadow a massive dollar depreciation to shrink the trade deficit to sustainable levels. Starvation Corner analyses (Obstfeld/Rogoff 2005, Krugman 2007) predicted that, in the case of a dollar crisis, fears of import-price inflation would persuade the Federal Reserve to tighten monetary policy and to sensibly reduce the US standard of living. The improvement of American net imports would have redistributed the recessionary impulse to America's trade partners, and particularly Japan and Europe, but also China and emerging countries.

Views about global imbalances showing either natural or structural reasons for their persistence relied on US fundamentals and the attractiveness of investing in American as- 
sets. These views shared with Keynes's Temptation option a declared confidence in the possibility of avoiding painful adjustments by the use of market mechanisms supplemented by tacit intergovernmental agreement. Globalisation would induce economies with banking systems poor at allocating capital to invest their excess savings in the United States (Cooper 2004): provided that American economic growth remained high and the ROW continued suffering from a financial asset shortage, therefore, the US deficit could happily persist over time, sustained by the historical positive gap between American earnings on foreign investments and payments to foreign investors in America. In the `Bretton Woods II (BWII) hypothesis (Dooley et al. 2003), Asian export-led growth with undervalued exchange rates, capital and trade controls, and international reserves accumulation, is considered as the stragegy of countries eager to cover that same road Europe and Japan traversed in the postwar period to regain a central position in the world economic system. In this view, both Asia and the currency floaters, primarily interested in defending their international investment position, have an interest in helping the central country finance its deficit. Despite their limits (the "globalizing economy" view fails to consider that the attractiveness of American assets may have more to do with the low saving rates of the United States than with their intrinsic qualities, as well as that the former leader of the international system, Britain, has already experienced a vanishing of yield differentials such as the one currently benefiting the United States; against the BWII hypothesis, one may call the attention on the heterogeneous nature of the group of countries of today's periphery and on the costs of sterilization for Asian countries; see Eichengreen 2004), such views rightly throw light on the systemic character of global imbalances.

A number of views share with Keynes's Justice option the idea that patterns of global interdependence are responsible for the surge and persistence of the imbalances, and the request for multilateral coordination to ensure their orderly unwinding. Examining the ongoing dependence of the ROW on net exports to the United States, the so-called "global codependency" views center on the »out of sync « relationship between the United States and foreign economic cycles (Mann 2005). The imbalances are thus found to result from the ROW using the United States as a source of foreign growth. As Kregel (2006) argues, they result from national policy choices, namely those chosen by developing countries in their path toward integration into international trade and finance, and those adopted by Europe to favour the continent's firms' attempt to acquire American assets and technology while keeping the value of their US subsidiaries' profits stable and protecting investment at home too. In other words, Asia and Latin America, but also Germany, the leader of a continent whose current account, as a whole, registers no significant surplus, de facto adopt the same strategy of current account surplus coupled with foreign lending as a substitute for the dangerous or unusable device of external and government borrowing. While China is the major engine of growth in Asia and outstandingly contributes to increased trade among developing countries, Germany's sluggish domestic growth, with restrictive monetary and fiscal policies and low-wages strategies, has certainly played a crucial role in postponing the multilateral response that multilateral imbalances require (see UNCTAD 2004): in a wellmanaged system, however, developed countries should grow through internal demand rath- 
er than by those policies that developing countries are (and should be) allowed to use in order to fill their gap with the former (Kregel 2006).

Although the current crisis is different in nature from the one that economists generally expected as the result of a disorderly unwinding of global imbalances (which may induce one to think that Temptation narratives are more robust than expected), the world economy is experiencing an impressive market-induced adjustment of the kind of those predicted by Starvation Corner analyses, seriously threatening economic growth in both developed and developing countries. Yet, the use of Keynes's international macroeconomics as a framework for today's views about this issue increases the relative importance of globalcodependency views and induces reasoning about global imbalances in terms of the contribution offered by the main players involved in sustaining global demand. Recognition of the mutual compatibility of national policy choices resulting in unprecedented imbalances at the international level strengthens the case for a multilateral response to the imbalances: the United States should boost its saving rate by taking fiscal action, while China should keep diversifying its economy and reduce national savings through public expenditures and orderly appreciation. A recovery of investment and consumption in Japan should promote the rotation of Asian demand from extraregional exports to the region itself, while emerging Asian countries should expand government expenditures and encourage household spending. Finally, Europe needs to sustain its growth through internal demand. Unfortunately, the packages of fiscal stimulus implemented to counteract the crisis follow the very pattern in the distribution of global demand growth that lies at the origins of global imbalances (UNCTAD 2009).

\section{Global monetary reform: Bretton Woods II, or expensiveness with instability}

A major puzzle the BWII narrative helps to investigate is the astonishing process of international reserves accumulation by developing countries, who have come to hold more than two thirds of the global international reserves and account for the most part of the increase in global reserves-GDP ratio. Reserve accumulation, mainly in dollars, is an essential part of surplus emerging countries' export-led growth strategies: according to Aizenman (2007), coordination failures lies at the basis of the Asian »hoarding game " wherein each mercantilist country - China in primis, unable as it is to control capital inflows and prevent appreciation directly and effectively - seeks to improve its own competitiveness on Western markets at the expenses of its neighbours. Yet the risk of capital losses, all the more so in a context of financial turmoil, is far from negligeable. After defining the social cost of self-insurance as the spread between yields deriving to central banks from liquid reserve assets and the private sector's cost of borrowing abroad, Rodrik (2006) finds one percentage point of GDP annually for developing countries to be lost in the process. Moreover, reserves accumulation tends to exclude alternative strategies to increase liquidity such as reducing short-term 
debt, and creates moral hazard problems and macroeconomic risks. For sure, international reserves provide self-insurance against sudden stops, and mitigate the magnifying effects of terms of trade shocks on real exchange rate volatility (Aizenman 2007). The reasonable expectation that countries with large reserves may perform better in the context of a global financial turmoil induces Dooley et al. (2009: I4) to predict that "emerging markets will be even more convinced that reserve accumulation and export-led growth are the safest development strategy in an uncertain world «. More generally, however, reserve accumulation is embedded in the general story of shrinking policy space: the strategy

"was taken in the context of the decision to adopt or reinforce the neo-liberal strategy of rapid financial liberalisation, unrelated to the development of either deep financial markets or mature and effective regulatory structures« (Cruz/Walters 2008: 666-67).

Keynes's proposal of a new international currency, the bancor, as the ultimate reserve asset of the system, is rightly commanding careful attention from economists and policy-makers who consider the use of a national currency, the dollar, responsible for the accumulation of "needless" reserves and global imbalances. Keynes's first major work, Indian Currency and Finance (1913; ICF) has so far been considered of much less use for this purpose, and unfortunately so (see Carabelli/Cedrini 2009a), since Keynes's suggestion to use the Indian model as a cornerstone and an incentive for a European monetary reform comes after a discussion of the nature and hoarding of international reserves as well as of the dynamics between debtor and creditor countries, i.e. the two most controversial issues of BWII. In ICF, Keynes attacked the Fowler Committee's proposal to introduce the pure, British version of the gold standard into the Indian system. The proper object of a good currency being "to combine cheapness with stability" (CW I5: 9I), he argued that »the prevailing form of currency in Asia« (70), the gold exchange standard, was a model also for advanced economies, who already held foreign balance for purposes of exchange stabilisation: it was not only a more "scientific and economical system « (62) than its pure version, but the »ideal currency of the future« $(C W \mathrm{I}: 25)$.

While Britain, the international short-term lender and banker, could quickly reduce the balance of indebtedness in her favour by the use of bank-rate policy, Keynes stressed,

»in countries where the money market is already a borrower rather than a lender in the international market [...] the bank itself must be at pains to become to some extent one [...] by itself entering the international money market as a lender at short notice, place itself in funds, at foreign centres, which can be rapidly withdrawn when they are required « (I8).

With respect to holding a much larger reserve of gold, Keynes added, "the new method combines safety with economy«. However, he remarked, "various stirring of the original sin of mercantilism [...] combine to make a powerful, natural, and yet unfounded prejudice $(125-26)$ against the use of reserves, even for the discharge of pressing obligations: India was not alone - although her problem was more fundamental, since all her resources, Keynes stressed, were required for capital expansion - in still having to learn that "gold 
reserves, although no doubt they serve some purpose when they are held for show only, exist to much better purpose if they are held for use also (I25). The sink of precious metals at a time of abundant international liquidity, Indias »love" of gold, "ruinous though it has been to her own economic development, has flourished in the past to the great advantage" of Europe (70). However, had Indian demand for gold shrunk abruptly over time, Keynes predicted, Europe and the whole world would have suffered from violent disturbances in the level of prices:

"If India is thus to turn the tables on the West, she must not delay too long. The time may not be far distant when Europe, having perfected her mechanism of exchange on the basis of a gold standard, will find it possible to regulate her standard of value on a more rational and stable basis. It is not likely that we shall leave permanently the most intimate adjustments of our economic organism at the mercy of a lucky prospector, a new chemical process, or a change of ideas in Asia« (7I).

What may appear as a "futuristic scenario involving a reversal of roles" (Chandavarkar 1989: 9I) was in truth a device introduced by the young economist to reinforce the case for European monetary reform driven by, and based upon, rationality. Keynes described the evolution of the Indian currency system since I899 as »silent «, »rapid « (CW I5: 67), and, most of all, unintended: neither the government nor the Fowler Committee of 1898 had contemplated the development of the gold exchange standard. He believed »the fact that the Government has drifted into a system and has never plainly set it forth " to be "responsible for a great deal of the misapprehension regarding its true nature which exists in the minds not only of the public, but also of some Government officials" (ibidem). Keynes's proposal of a European gold exchange standard was, on the contrary, an example of rational reform, destined to replace the "undesigned outcome of instinct " with "schemes conceived by the mind " ( $C W_{\mathrm{I}}$ : 453$)$. A programme later explicitly endorsed in the Tract on Monetary Reform: "we must free ourselves from the deep distrust which exists against allowing the regulation of the standard of value to be the subject of deliberate decision $\left(C W_{4}: 36\right)$. Best placed to decide and act precisely in those cases in which uncertainty and ignorance force individuals to adhere to average opinion and conventions, public institutions are required, in Keynes's view, to modify public opinion and establish a new, less harmful convention. The alternative to gold, he wrote in the Tract, was just »our existing system, but worked self-consciously and for a wise, deliberate purpose ( $C W_{4}$ : I6I). In the days of the I9I4 crisis, Keynes had accused Britain's debtors of preferring "sterile hoards to the fulfilment of their obligations" (CW II: 259): «although many countries hold large quantities of gold, there are but few which pursue a rational policy in regard to it. At considerable cost they build up large reserves in quiet times presumably with a view to the next crisis; but when the crisis comes, mistaken policy renders them as little able to use gold as if it were not there at all « (247). Wondering why European countries had deliberately abandoned the "purposes for which it is rational to hold a reserve (315), Keynes even came to welcome the advent of war, which could cause gold to be "deposed from its despotic control over us and reduced to the position of a constitutional monarch«, until »a new chapter of history will be opened. Man will have made 
another step forward in the attainment of self-government, in the power to control his fortunes according to his own wishes. We shall then record the subtle, profound, unintended, and often unnoticed influences of the precious metals on past historical events as characteristic of an earlier period « (3I7).

In ICF, anticipating his views in the Forties, Keynes offered the picture of an international monetary system able to conciliate, aptly managed as it was through the use of exchange reserves held in the international financial centres, the interests of debtors with those of creditor nations (the sreserves are to be used not shown ^ principle informs the ICU plan as well, which is intended to discourage hoarding of surpluses and the deflationary effects these may have on the world economy; the proposal of a new global currency, the bancor, is the conclusion of a path, from commodity to fiat international money, that Keynes started off on writing ICF). The parallel between his early look at Asia for hints of monetary reform and current, Asia-driven new features of global interdependence shows our inability to cope with the spectacular effects of "a change of ideas in Asia", that is the passage - forced by the adoption of neo-liberalism and financial liberalisation under Western pressures - from external borrowing to "undervaluation-cum-intervention « as development strategy. Asia has now »turned the tables on the West", but the West has not yet learnt how to control »the most intimate adjustments« of its "economic organism». Contrary to Keynes's desired order, BWII combines expensiveness with instability. This is due, on one hand, to the use of a national currency as the global reserve currency and the instrument for international payments, which compels the reserve country to face chronic deficits (see Greenwald/Stiglitz 2008). While in the golden age of Bretton Woods the ultimate creditor country was willing and able to offer a permanent free lunch for all by accepting the major responsibility for solving international payments imbalances, the mercantilist tendencies of BWII cannot but produce a deflationary environment (Davidson 2008). On the other hand, the "fallacy of composition effects that feed into global imbalances" (Ocampo 2007: I2) have much to do with emerging countries' demand for protection from pro-cyclical capital inflows accompanied by limited possibilities to adopt counter-cyclical policies.

True, emerging markets have used exchange reserves to protect themselves against banking problems, capital flights and associated currency depreciations. Yet, as Aizenman notes,

"the reluctance of many countries to draw on their reserve holding raises the possibility that they may now suffer less from the well-known sfear of floating than from a ,fear of losing international reserves‘, which may signal a deterioration in the credit worthiness of a country. Mitigating this concern should be the prime responsibility of the international financial institutions" (Aizenman 2009: 17).

In this sense, the early economics of Keynes and his proposal of rational monetary reform lead one to conclude that the unintended evolution which has transformed global imbalances and reserve accumulation into an engine of global growth, under the assumption of ever-growing American demand for foreign goods, does not make them reasonable, nor does it justify inactivity with regard to their persistence. Economic anxieties, more than the aggressive or defensive behaviours they produce in a neo-liberal environment, are likely to 
explain the BWII logic of reserve hoarding. The antidote to such anxieties may only come from rational reform plans, such as an updated version of Keynes's ICU scheme, deliberately designed to counteract them.

\section{Freedom to choose and policy space}

With its stress on the universality of right p paths to economic growth, the Washington Consensus paradigm (see Cedrini 2008) is a perfect symbol for the post-Bretton Woods world's inability to cope with the dilemmas of the international system learned the lesson, but the BWII system has de facto reached another impasse. The rembedded liberalism $`$ of the Bretton Woods system rested on the 'free lunch for all offered by America via the Marshall Plan, reflecting the United States' decision to accept

"the Keynes Plan's suggestion that it is in the best interest of all nations if the major creditor nation bears the major burden of reducing trade imbalances and international payments adjustments« (Davidson 2007: 145).

Davidson's project of a new international clearing union modelled on Keynes's plan aims therefore to create a Keynesian global order possessing a built-in expansionary bias, rather than having to rely on the happy accident of the leader's commitment to a public-spirited behaviour.

The interpretation that is here advanced of the proposal of an American gift to Britain in 1945, stressing the substantial continuity it provides with his Bretton Woods plans for global reform, may offer further elements to grasp the essence of Keynes's quest for a new global order. Paradoxically enough, given the contrast with the interpretation of the ICU plan as an rautomatic surrender of surpluses, Keynes's proposal of an American gift seems entirely inscribed into the sphere of freedom. Keynes never abandoned the idea of making the Americans themselves offer the gift, as the result of a sincere appreciation of Britain's effort in financing the war and her future expected difficulties - not dissimilarily, at the end of the First World War, Keynes had stressed that the Americans did not have any »obligation" ( $C W$ I8: 300) to comply with his proposals for the settlement of inter-allied debts. Moreover, while stressing the need to avoid a bargain between the two powers, and insisting on the "psychological atmosphere of the free gift«, Keynes demonstrated that his proposal, instead of offering an ambiguity-solving device to come to an agreement otherwise impossible to obtain, was based exactly on that structural uncertainty which, exposing the giver to the risk of no return, can lead actors that previously regarded each other as rivals to gamble on mutual trust (see Caillé 1998).

As any > first ' gift, the American gift was, in Keynes's view, the first element of a complex dynamics that required Britain to reciprocate. Yet, Britain's countergift was but the promise to help the Americans develop the kind of post-war world on which both countries, not only the donor but also the donée, had set their hearts: only a gift, Keynes argued, could allow Britain to face this obligation. The Americans, he wrote, were given the historical chance to 
»make us an offer, not so much generous as just, using their financial strength not as an instrument to force us to their will, but as a means of making it possible for us to participate in arrangements which we ourselves prefer on their merits if only they can be made practicable for us" $(C W 24: 272)$.

The difference between the loan finally offered by the Americans and Keynes's desired American gift lay in the opposite repercussions they would have respectively had on the receiver's freedom to choose. As a means of forcing Britain to the American will, a loan would have compelled London to passively accept the American conception of the international economic system. As wan act that widens the scope of freedom for the members of a society" (Godbout I998: 190), on the contrary, a gift would have granted Britain the freedom to proactively choose and help to shape the multilateral option.

For Keynes, freedom is first of all freedom from economic necessity. Some key passages of Keynes's diplomacy during World War II clearly echo the anti-utilitarianism of his essay Economic Possibilities for Our Grandchildren, his view of wealth as no more than the material precondition for the enjoyment of a happy life and the possibility of individual choice of ends, his vision of the international economic problem as "a transitory and an unnecessary muddle« ( $C W_{9}$ : xvii). However, freedom is for Keynes, more exactly, freedom to choose (see Carabelli/Cedrini 2009b). In the General Theory, Keynes justifies his calls for »central controls" (CW 7: 379) as a means to attain full employment while safeguarding the »traditional advantages of individualism«, which

»is the best safeguard of personal liberty in the sense that, compared with any other system, it greatly widens the field for the exercise of personal choice. It is also the best safeguard of the variety of life, which emerges precisely from this extended field of personal choice« $(380)$.

Public institutions such as the ICU itself have for Keynes the »duty to be altruistic, in defence of the individual " (Carabelli/De Vecchi 20oI: 244) and his right to autonomous judgement. Keynes defended the Anglo-American negotiations in the Forties as the

"first great attempt at organizing international order out of the chaos of the war in a way which will not interfere with the diversity of national policy yet which will minimize the causes of friction and ill will between nations" $\left(C W_{24}: 608\right)$.

While the unrestricted laissez-faire of the late gold standard and interwar period had "mistake[n] private licence for public liberty « (622), his desired international system should be able to compensate the limitation of policy space which is required by global interdependence through a multilateral system explicitly designed to reduce the frictions between national autonomy and adherence to an international regime. A system, in other words, able to solve the dilemmas it raises by managing the co-habitation of different varieties of national capitalism instead of imposing them a one-size-fits-all set of right policies. Overseas Financial Policy in Stage III may now finally appear as a tester of the leader's willingness to comply with the revolutionary spirit of the desired new system, despite the rejection of the 
Ifreedom-enhancing proposals advanced by Keynes for Bretton Woods. If Keynes is ,fashionable again, this may be due to the core message of his work as an international negotiator: a new successful international system of national capitalisms will be more likely based on consensus upon freedom rather than against it, and one which establishes its rules of the gamer on the need to enlarge, rather than restrict, national autonomy and policy space.

\section{Concluding remarks}

In a way, this paper has tried to demonstrate, to use Kirshner's words, that

"while it is worth revisiting Keynes for what he wrote about - for the revolution in macroeconomics, and the relevance of his ideas for [some] pressing contemporary questions [...] - it is also worth remembering how he did it, and why«. (Kirshner 2009: 539)

Today's calls upon Keynes for a new era of prosperity rely upon the recognition of the public-spirited character of his international economics and diplomacy, that is on the belief that his work was directed toward the establishment of a »sounder political economy between all nations" ( $C W 25: 43)$. Yet the unprecedented appeal of Keynes's reform plans challenges a well-established tradition in the history of economic thought that may be named, using the subtitle of the third volume of Skidelsky's biography of Keynes, the Fighting for Britain view of Keynes's international economics and diplomacy. Skidelsky tends to incorporate Keynes's plans for global reforms in the Forties into the more general story of Britain's (and other debtors') attempt to secure overdraft facilities for the post-war period (see Skidelsky 2000: 208), thereby ending with conditioning the evaluation of their historical significance to a disenchanted account of the negotiations of the 1945 American loan to Britain, and of Keynes's efforts to save his financially exhausted country and its Empire from the "American conception of the international system« $\left(C W_{24}\right.$ : 6I $)$.

By revisiting the 'focus and method of Keynes's work in international economics and showing the continuity they provide with the methodological positions he adopted in treating the economic material in his theoretical writings, we have tried to prove that the 'Fighting for Britain` view has shaky foundations. Keynes was fighting through Britain when dealing with the transition to the postwar orders, in the attempt to establish shared responsibilities principles as a means to ensure an orderly unwinding of international imbalances; he was fighting through Britain when devising a rational international monetary system which could transform the historical advantages of the prewar gold standard into permanent features of the postwar regime; he was fighting through Britain when posing the bases for a global system of national capitalisms able to promote, rather than repress, national policy space. It really seems time to rediscover Keynes: not only his specific recommendations for global reform, but also, and foremost, the general vision he developed for the analysis of the global economic order throughout his whole life, which may prove precious in identifying the major shortcomings of the current `non-system ‘ and help strength- 
en the case for coordinated multilateral international adjustment, rational monetary reform, and enhanced policy space.

\section{References}

Aizenman, J. (2007): Large hoarding of international reserves and the emerging global economic architecture, National Bureau of Economic Research Working Paper, No. 13277.

Aizenman, J. (2009): On the paradox of prudential regulations in the globalized economy. International reserves and the crisis: A reassessment, National Bureau of Economic Research Working Paper, No. I4779.

Bernanke, B.S. (2005): The global saving glut and the U.S. current account deficit, Remarks at the Sandridge Lecture, Virginia Association of Economics, Richmond, Virginia, March Io, URL: http://www.federalreserve.gov/boarddocs/speeches/2005/200503102/default.htm.

Caillé, A. (1998): Il terzo paradigma. Antropologia filosofica del dono, Torino: Bollati Boringhieri.

Carabelli, A. (1988): On Keynes's Method, London: Macmillan.

Carabelli, A., Cedrini, M. (2009a): Indian currency and beyond. The legacy of the early economics of Keynes in the times of Bretton Woods II, SEMeQ Working Paper, No. I2/o9.

Carabelli, A., Cedrini, M. (2009b): The economic problem of happiness. Keynes on happiness and economics, SEMeQ Working Paper, No. I3/o9.

Carabelli, A., Cedrini, M. (20Io): Current global imbalances: Might Keynes be of help?, in: Marcuzzo, M.C., Hirai, T., Bateman, B. (eds.), The Return to Keynes: Keynes and Keynesian Policies in the New Millennium, Cambridge, Mass.: Harvard University Press, 257-274.

Carabelli, A., Cedrini, M. (forthcoming): Keynes and the complexity of international economic relations in the aftermath of World War I, in: Journal of Economic Issues.

Carabelli, A., De Vecchi, N. (200I): Individuals, public institutions and knowledge: Hayek and Keynes, in: Porta, P., Scazzieri, R., Skinner, A. (eds.), Knowledge, Social Institutions and the Division of Labour, Aldershot: Elgar, $229-248$.

Cedrini, M. (2008): Consensus versus freedom or consensus upon freedom? From Washington disorder to the rediscovery of Keynes, in: Journal of Post Keynesian Economics, 30(4), $499-522$.

Cedrini, M. (20I0): What was Keynes fighting for? A Maussian perspective of Keynes's economic diplomacy, paper presented at the workshop »Revisiting the Boundaries of Economics: A Historical Perspective«, Collegio Carlo Alberto, Moncalieri (Torino), April I6.

Chandavarkar, A.G. (1989): Keynes and India. A Study in Economics and Biography, London: Macmillan.

Chinn, M.D. (2005): Getting serious about the twin deficits, Council on Foreign Relations Special Report Io, September, URL: http://www.cfr.org/content/publications/ attachments/TwinDeficitsTF.pdf.

Cooper, R. (2004): US deficit: It is not only sustainable, it is logical, in: Financial Times, October 3I, Ar5, 2004.

Cruz, M., Walters, B. (2008): Is the accumulation of international reserves good for development?, in: Cambridge Journal of Economics, 32(5), 665 - 681. 
Davidson, P. (2007): John Maynard Keynes, New York: Palgrave Macmillan.

Davidson, P. (2008): Reforming the world's international money, in: Real-World Economics Review, 48(6), 293-305.

De Cecco, M. (1979): Origins of the post-war payments system, in: Cambridge Journal of Economics, $3(\mathrm{I}), 49-6 \mathrm{I}$.

De Cecco, M. (200I): John Maynard Keynes, in: Rivista di storia economica, I7(3), 373 - 382.

Dimand, R.W. (2006): Keynes and global economic integration, in: Atlantic Economic Journal, 34(2), I75 - I82.

Dooley, M.P., Folkerts-Landau, D., Garber, P. (2003): An essay on the revived Bretton Woods System, National Bureau of Economic Research Working Paper, No. 997I.

Dooley, M.P., Folkerts-Landau, D., Garber, P. (2009): Bretton Woods II still defines the international monetary system, National Bureau of Economic Research Working Paper, No. I473I.

Eichengreen, B.J. (2004): Global imbalances and the lessons of Bretton Woods, National Bureau of Economic Research Working Paper, No. I0497.

Fleming, G. (2000): Foreign investment, reparations and the proposal for an international bank: Notes on the lectures of J.M. Keynes in Geneva, July 1929, in: Cambridge Journal of Economics, 24(2), I39- I5I.

Godbout, J.T. (1998): The moral of the gift, in: The Journal of Socioeconomics, 27(4), $557-570$.

Godbout, J.T. (in collaboration with A. Caillé) (2000): The World of the Gift, Montreal: McGillQueen's University Press.

Greenwald, B., Stiglitz, J.E. (2008): A modest proposal for international monetary reform, Paper presented at the International Economic Association Meeting, Istanbul, June, URL: http://www.agn.gov.ar/debitum/nro_6/Biblioteca_virtual/Documentos/ Stiglitz_2008_A_Modest_Proposal.pdf.

Keynes, J.M. (1971 - 1989): The Collected Writings of John Maynard Keynes, Johnson, E., Moggridge, D.E. (eds.), 30 volumes, London: Macmillan.

Kirshner, J. (2009): Keynes, legacies and inquiries, in: Theory and Society, 38(5), 527 - 54I.

Kregel, J.A. (2006): Understanding imbalances in a globalised international economic system, in: Teunissen, J.J., Akkerman, A. (eds.), Global imbalances and the US debt problem. Should developing countries support the US dollar?, The Hague: Fondad, I49 - I73.

Krugman, P. (2007): Will there be a dollar crisis?, in: Economic Policy, 22(5I), $435-467$.

Mann, C.L. (2005): Breaking up is hard to do: Global co-dependency, collective action, and the challenges of global adjustment, in: CESifo Forum I, 16 - 23.

Markwell, D.J. (I995): J.M. Keynes, idealism, and the economic bases of peace, in: Long, D., Wilson, P. (eds.), Thinkers of the Twenty Years' Crisis. Inter-war Idealism Reassessed, Oxford: Clarendon Press, $189-2 \mathrm{I} 3$.

Markwell, D.J. (2006): John Maynard Keynes and International Relations. Economic Paths to War and Peace, Oxford: Oxford University Press.

Moggridge, D.E. (1986): Keynes and the international monetary system $1909-46$, in: Cohen, J.S., Harcourt, G.C. (eds.), International Monetary Problems and Supply-Side Economics: Essays in Honour of Lorie Tarshis, London: Macmillan, 56 - 83. 
Moggridge, D.E. (1992): Maynard Keynes: An Economist's Biography, London: Routledge.

Newton, S. (2000): A svisionary hope frustrated: J.M. Keynes and the origins of the postwar international monetary order, in: Diplomacy and Statecraft, II(I), I89-2IO.

Obstfeld, M., Rogoff, K. (2005): The unsustainable US current account position revisited, Paper presented at the NBER conference $\mathrm{G}_{7}$ Current Account Imbalances: Sustainability and Adjustment«, Newport, RI, June I - 2, URL: http:/www.nber.org/books/ curracct/obstfeld-rogoff6-20-05.pdf.

Ocampo, J.A. (2007): The instability and inequities of the global reserve system, DESA Working Paper, No. 59.

Pressnell, L.S. (1986): External Economic Policy since the War. Vol. I: The Post-War Financial Settlement, London: Her Majesty's Stationery Office.

Rodrik, D. (2006): The social cost of foreign exchange reserves, in: International Economic Journal, 20(3), 253-266.

Skidelsky, R. (2000): John Maynard Keynes. Vol. 3: Fighting for Britain, 1937- 1946, London: Macmillan.

Truman, E.M. (2005): Postponing global adjustment: An analysis of the pending adjustment of global imbalances, Peterson Institute for International Economics Working Paper, No. 05-6, July.

Turnell, S. (2002): Keynes, economics and war: A liberal dose of realism, Research Papers of the Department of Economics of Macquarie University, No. 0207.

UNCTAD (2004): Trade and Development Report. Policy Coherence, Development Strategies and Integration into the World Economy, New York and Geneva: Unctad.

UNCTAD (2005): Trade and Development Report. New Features of Global Interdependence, New York and Geneva: Unctad.

UNCTAD (2006): Trade and Development Report. Global Partnership and National Policies for Development, New York and Geneva: Unctad.

UNCTAD (2009): Trade and Development Report. Responding to the Global Crisis, Climate Change, Migration and Developmen, New York and Geneva: Unctad.

UNPGA (2009): Report of the Commission of Experts of the President of the United Nations General Assembly on Reforms of the International Monetary and Financial System, URL: http:/www.un.org/ga/president/63/commission/financial_commission.shtml.

Vines, D. (2003): John Maynard Keynes 1937 - I946: The creation of international macroeconomics. A review article of John Maynard Keynes 1937 - 1946: Fighting for Britain by Robert Skidelsky, in: The Economic Journal, I13(488), 338 - 361.

Williamson, J. (198I): Review of The Collected Writings of John Maynard Keynes. Volume XXV. Activities 1940 - 1944. Shaping the Post-War World. The Clearing Union; The Collected Writings of John Maynard Keynes. Volume XXVI. Activities 194I - 1946. Shaping the PostWar World. Bretton Woods and Reparations, in: The Economic Journal, 9I(362), 54I - 544.

Wolf, M. (2005): Will Asian mercantilism meet its Waterloo?, Richard Snape Lecture, Melbourne, November I4, URL: www.pc.gov.au/lectures/snape/wolf/wolf.pdf.

Zhou, X. (2009): Reform the International Monetary System, The People's Bank of China, Beijing, URL: www.pbc.gov.cn/english. 
